\title{
Should We Compare Laws or Cultures?
}

\author{
HEIKE JUNG*
}

\section{Introduction}

Comparatists have always known that a meaningful comparison cannot be confined to narrow positivistic exercises. They have learned to extend the focus to the institutional and systematic context. ${ }^{1}$ Moreover, they have become increasingly aware of the fact that, in order to grasp the gist of another legal system ('what makes them tick'), one has to reach out for the socio-cultural characteristics. Some culturalists' even claim: 'la comparaison des droits sera CULTURELLE ou elle ne sera pas.' This pronounced statement raises several related questions:

1. How autonomous are the law and its administrators?

2. What do the terms 'culture' and 'legal culture' mean?

Heike Jung is Professor Emeritus of Criminal Law, Criminal Procedure, Criminology and Comparative Criminal Law at the University of Saarland. - Updated and revised English version of my contribution 'Rechtsvergleich oder Kulturvergleich?' to the Festschrift für Frisch (Duncker \& Humblot 2013) p. 1467.

$1 \quad$ Already Mittermaier, Die Lehre vom Beweise im deutschen Strafprozesse: nach der Fortbildung durch Gerichtsgebrauch und deutsche Gesetzbücher in Vergleichung mit den Ansichten des englischen und französischen Strafverfahrens (Heyer 1834) p. 42, refuted pointillistic loans from other systems and pleaded in favour of respecting the organic context: 'Es ist ein schwer zu tadelnder Fehler vorzüglich neuerer Gesetzgeber, welche verleitet durch den Reiz der Neuheit und durch das Streben nach Originalität und von dem Wunsche beseelt, allen Partheien zu gefallen, gerne aus allen möglichen Legislationen einzelne Theile herausnehmen, nicht beachtend, dass diese Theile in der Gesetzgebung, welcher sie angehören, in einem organischen Zusammenhang mit andern Einrichtungen stehen, von denen sie nicht losgerissen werden dürfen, wenn nicht ein Gebäude ohne alle Harmonie entstehen soll.

2 Legrand, Le droit comparé, 5th ed. (Presses Universitaires de France 2015) p. 123 ('The comparison of legal systems needs to be CULTURAL, otherwise it is no comparison at all').

This is an Open-access article distributed under the terms of the Creative Commons Attribution 3.0 Unported License (http://creativecommons.org/licenses/ by/3.0/), permitting all use, distribution, and reproduction in any medium, provided the original work is properly cited. 
3. Is a comparison of legal culture feasible and, if at all, by which means and methods?

4. What is the aim of such a demanding enterprise? Explaining the differences or foster harmonization?

These questions come close to a questionnaire of what comparative method and comparative law is about. In actual fact, we reach out for no less than the role of law in society. If law is essentially an autonomous entity, though to some extent tainted by specificities of the particular society, its administrators, i.e. the lawyers, will be able to cope with any positivistic content. Hence, legal transplants and harmonization appear to be manageable projects. If law is primarily conceived of as a product of a particular culture, harmonization moves will be heading for deep waters and comparison will be mainly restricted to explaining the differences. Since globalization and international cooperation call for a certain harmonization of legal systems, 'culturalists' tend to hinder the comparative agenda. According to them, any large scale harmonization will rather amount to an impossible mission.

This controversy has triggered a vivid debate among comparatists about the role of culture. ${ }^{3}$ One thing goes for sure: cultural aspects cannot be discarded in the comparative enterprise. Yet, there is no general answer as to their concrete impact on research projects in comparative law. It may well be that with some (more technical) issues we need not bother at all, whereas others do need a cultural fine-tuning. In a way, this exercise is fascinating and cumbersome at the same time, fascinating because we are heading for an intellectual adventure, cumbersome because the wide concept of law meets the even wider concept of culture. Therefore some lawyers even try to avoid the culture debate altogether assuming that the reference to culture is a cover-up for methodological sloppiness. ${ }^{4}$ Even some sociologists take a reluctant approach when it comes to using the term 'culture' in the context of law. ${ }^{5}$

So much difficulty calls for a reduction of complexity. This accounts in particular for the term 'culture'. It fills libraries. Depending on the subject matter and the specific

3 E.g. Cotterrell, Comparative Law and Legal Culture in The Oxford Handbook of Comparative Law, eds. Reimann and Zimmermann (Oxford University Press 2008) p. 209; Bell, De la culture in Comparer les droits, résolument, ed. Legrand (Presses Universitaires de France 2009) p. 247, Nelken, Rethinking Legal Culture in Law and Sociology, Current Legal Issues 2005, Vol. 8, ed. Freeman (Oxford University Press 2006) p. 200; Rosen, Law as Culture (Princeton University Press 2008).

4 Hörnle, Unterschiede zwischen Strafverfahrensordnungen und ihre kulturellen Hintergründe, 117 Zeitschrift für die gesamte Strafrechtswissenchaft (2005) p. 801 et seq. hints at this position.

$5 \quad$ Cf. Friedman, The Republic of Choice: Law, Authority, and Culture (Harvard University Press 1990) p. 95: "Legal culture" is a phrase conveniently used for norms and ideas about law, but it is an abstraction, and a slippery one. 
national context, it may have differing connotations. Linking the term with law or with a particular legal system does not bring more clarity. Of course, 'legal culture' may pass as a cipher for the idiosyncrasies of a legal order or a legal style ${ }^{6}$ thus providing a rough orientation. But what do we mean by 'cipher' or by 'idiosyncrasy'? Are we still moving in legal territory or have we already transgressed the borders and where to? Where does culture turn into law and law into culture?

A 'culturalist' approach is akin to Montesquieu's $\mathrm{s}^{7}$ relativism. The relativity may vary according to the character of the particular project, its topic, its purpose and its dimension. Also, the increasing interaction on a global scale favours an increasing sensitivity for a certain universalism which competes with a growing respect for the diversity of legal traditions. Hence, the idea of harmonization, at least of some areas of law, cannot be rejected a limine. This statement is not meant to anticipate the outcome of this study. I just want to warn of a false antagonism.

\section{The Interdisciplinary Background}

The fact that law is impregnated by culture is no news. We recall older (German) controversies about whether or not law is a 'cultural science' (Kulturwissenschaft) ${ }^{8}$ which dwell on the notion that law is a science after all. Still, the sense of comparatists for the cultural component of law was not as developed as one might think. Though Montesquieu, one of the founding fathers of comparative law, ${ }^{9}$ had paved the way for such considerations, it took two centuries until they really caught on in the community of comparatists. The duo of sociology and criminology has, despite some differences in the fine-tuning, sensitized comparatists to look beyond the positivistic façade of legal systems and to discover the societal mould of the normative material which made their analytical endeavour turn into a new direction. Again, already Montesquieu had alluded to the idea that law is an instrument of social control. ${ }^{10}$ But only a more developed sociology of law made us aware of the consequences, thus altering our understanding of criminal law and criminal

6 Cf. Mankowski, Rechtskultur, 64 JuristenZeitung (2009) p. 321; and, more recently, Mankowski, Rechtskultur (Mohr Siebeck 2016) p. 2. In a way, the article in the JuristenZeitung preludes his impressive magnum opus.

7 For a general account of Montesquieu's philosophy of law e. g. Goyard-Fabre, La philosophie du droit de Montesquieu (Kliencksieck 1979).

$8 \quad$ E.g. Senn and Puskaś (eds.), Rechtswissenschaft als Kulturwissenschaft?, Beiheft Nr. 115 Archiv für Rechts- und Sozialphilosophie (Steiner 2008).

9 On the role of Montesquieu as a comparatist cf. Constantinesco, Rechtsvergleichung, Vol. I (Heymanns 1971) p. 78.

10 Cf. Book VI, Chapter XII of his De l'esprit des lois ('De la puissance des peines'). 
justice. Their functioning, institutional design and societal context are subject to a more conscious reflection today.

This does, however, not give a sufficient explanation, since sociology and criminology had already flourished before the relationship between law and culture has attracted our interest. Here, two related developments come into play: the 'cultural turn' initiated by semantics on the one hand, ${ }^{11}$ and anthropology, ethnology and ethnography on the other. They have, in a hitherto unknown sharpness, brought 'context' to the forefront. This term, despite or because of its vagueness, describes perhaps best what 'law and culture' is about. It is difficult to assess the impact of these different disciplines separately since they are linked with each other. I daresay that we have profited most from ethnology. ${ }^{12}$ The overspill into other disciplines has led to a refinement in the general methodological repertoire of the social sciences with repercussions on comparative law as well (see the role of participating observation ${ }^{13}$ ). Generally speaking, empiricists in the social sciences which used to believe in quantitative methods and 'hard facts' have increasingly turned towards qualitative approaches. ${ }^{14}$ Geertz has propagated the idea of 'the meaningful detail' without giving us enough guidance as to how and where to look for it. ${ }^{15}$ Those comparatists who had, from the outset, made an effort to back their studies by field-work in order to get some idea of the 'legal climate' felt reassured. Yet, at the same time, research projects became more and more demanding.

The political changes and these scientific developments have gone hand in hand to promote a culture-oriented comparison. Globalisation has to some extent promoted a platform of common understanding, yet it has also catapulted local sites and developments into the limelight of a world-wide attention. It has sensitized for frictions and differences. In that sense, it has rather been a booster for an ethnology which takes note of the tensions between the local and the global. ${ }^{16}$ Thus 'cultural identity' and 'global trends' are concomitant features in contemporary societies. This certain contradiction (or is it an amalgam?) between universalism and diversity is of major concern for those sociologists who try to explain a world which seems to bid farewell to societies. ${ }^{17}$

11 E.g. Bachmann-Medick, Cultural Turns (Rowohlt 2006).

12 See in particular the classical studies by Gluckman, The Judicial Process among the Barotse of Northern Rhodesia (The Free Press 1955); Roberts, Order and Dispute: an Introduction to Legal Anthropology (Penguin Books 1979); for a general overview cf. Rosen 2008.

13 On the role of participating observation in comparative law e.g. Jung, Über die Beobachtung als Methode der Strafrechtsvergleichung in In dubio pro libertate: Festschrift für Klaus Volk zum 65. Geburtstag, eds. Hassemer, Kempf and Moccia (Beck 2009) p. 223.

14 E.g. Kunz, Die wissenschaftliche Zugänglichkeit von Kriminalität (Verlag für Sozialwissenschaften 2008).

15 Geertz, The Interpretation of Cultures (Basic Books 1973) p. 23

16 Cf. Abélès, Anthropologie de la globalisation (Payot 2008).

17 E. g. Touraine, La fin des sociétés (Seuil 2013) p. 496 et seq. 
As a result, law has increasingly become a matter of 'meta-legal' scrutiny. This has fostered a new perception of law which is no longer being conceived of as a business of mere interpretation of texts. Rather we are keen to reach out for the background. Moreover, we have learned that law consists of a sequence of institutional acts which forge social cohesion by offering a formalized frame for social interaction. Expanding the dictum that 'Justice must be seen to be done' ${ }^{18}$ we have also revisited the role of rituals in law building upon a solid body of interdisciplinary research on the matter. ${ }^{19}$

It is self-evident that the culture paradigm has been adopted with different intensity on the academic scene. Whereas studies in 'intercultural communication' appear to be the natural extension of the traditional curriculum of the language department, a syllabus of business administration which covers culturally differing managerial styles is more noteworthy. ${ }^{20}$ Law departments proceed only reluctantly. Even comparatists have not been overly keen to embark on this venture for fear of the complexity of the task. Comparing different legal systems in a two hours course is difficult enough even on a positivistic basis.

\section{From Culture to Legal Culture}

There is no easy way to define 'culture'. The term lacks precision. It seems that again ethnologists can provide help since they were the first to use the term on a larger scale. ${ }^{21}$ The concept seems to have originated from Germany. Its meaning is, to some extent, context-bound. ${ }^{22}$ Ethnologists tend to associate mythology, philosophy, language, arts and customs with it, putting the emphasis on customs. In more general terms, we could speak of 'life style'. At the same time, the term may, being related to 'arts', hint at a particular elevated life style, at something distinct from the ordinary: 'Par culture on désignait ce qu'il $y$ a de plus élevé et de précieux dans la société. ${ }^{23}$ This certain refinement may be related to any area of life. If we speak of an eating culture we do not refer to the mere consumption of food, but rather to a specific eating habit, perhaps to characterize the French, Spanish,

18 Lord Hewart in: R. v. Sussex Justices, ex parte McCarthy (1924) 1 KB 256, 259.

19 Deprez, Rituel judiciaire et procès pénal (L. G. D. J. 2009); Jung, Rituals and Procedure in Visions of Justice: Liber Amicorum Mirjan Damaska, eds. Ackerman, Ambos and Sikiric (Duncker \& Humblot 2016) p. 259.

20 Cf. Morschett, Schramm-Klein and Zentes, Strategic International Management, 3rd ed. (Gabler Springer 2015) p. 203 et seq.

21 E.g. for the following in particular Abélès 2008 p. 63 et seq.

22 Cf. Greve, The Historical Roots - European Legal Cultural Traditions, (Juridiska Föreningen i Finland 2010) p. 482.

23 See Abélès 2008 p. 64 ('The term culture hinted at something more elevated and precious in society'). 
Indian or Chinese cuisine. The term political culture insinuates a civilized political debate.

This is, however, not implied when we associate a medium like language or law with culture. In this case, we focus on a particular social background which, with law, accounts for the special character of a legal system. Yet, even in connection with law, the use of the term 'culture' may also refer to a particular laudable practice. In Germany, Häberle has, for example, popularized the use of the term 'Grundrechtskultur'24 which, somewhat related to the term 'politische Kultur' implies that public life is not just guided by the Grundrechte as a normative frame and limitation, but inspired by their philosophy as an overarching aspiration. It may well be that this positive connotation is a German lawyer's import into the general usage of the term. The title of Garland's study 'The Culture of Control $^{25}$ rather reveals 'sociological neutrality'. When we speak of the 'American gun culture' we can even sense a pejorative connotation.

Be that as it may: we have to cope with a certain vagueness which invites subjectivism. Speaking of 'Rechtskultur' we leave the more or less nicely circumscribed terrain of legal positivism and reach out for justice as an inspiration and regulative ideal which may well produce a variety of manifestations. In this general sense, law is culture. ${ }^{26}$ Or, genetically speaking: 'the concept of law is itself a product of a specific culture. ${ }^{27}$

In general, cultural aspects will rather tend to pervade key issues, general characteristics and modes of thinking. ${ }^{28}$ But often enough details - see Geertz - will also be imbued by culture. The search for the background melody of the system has to be accompanied by an institution- and actor-oriented approach and a look at the status of the law, i.e. the interdependence with the state and society, the tradition of conflict resolution etc. Modern terminology like 'governance' may be of help to get one's bearings since it captures the general issue of power and regulation irrespective of any preconceived notion of state structure.

The religious background plays an increasingly important role. Though it is not easy, if not impossible, to disentangle religion from general political considerations ${ }^{29}$ religion is increasingly - in the aftermath of Huntington's famous article 'The Clash of Civilizations? ${ }^{30}$ - conceived of as a divide which triggers or boosts many a conflict in today's

24 Häberle, Grundrechtsgeltung und Grundrechtsinterpretation im Verfassungsstaat, 44 JuristenZeitung (1989), pp. 913 and 915.

25 Garland, The Culture of Control: Crime and Social Order in Contemporary Society (Oxford University Press 2001).

$26 \quad$ See Mankowski 2009 p. 322; idem 2016 p. 5.

$27 \quad$ Raz, On the Nature of Law, 82 Archiv für Rechts- und Sozialphilosophie (1996) pp. 1 and 4.

28 E.g. Galtung, Struktur, Kultur und interkultureller Stil, 11 Leviathan (1983) p. 303.

29 For a general outlook on the issue e.g. Graf and Meier (eds.), Politik und Religion (Beck 2013).

30 Huntington, The Clash of Civilizations, 72, Number 3, Foreign Affairs (1993) p. 22. 
world. The history of legal transplants has shown to which extent religious beliefs steer and modulate the approach to law and its positivistic emanations. Likewise, societies may be distinguished according to the impact of religion on public life.

In view of all this, we need a specialist for the general view, i.e. for bringing things together. Our search is hampered by the fact that those who are engaged in the matter do not necessarily agree on the premises of this undertaking. Whereas some focus on the general impact of culture on legal culture others try to delineate concrete indicators for a more meaningful comparison. Thus Friedman refers to 'attitudes and values ${ }^{31}$ whereas Blankenburg underlines the interplay between law and its institutions, legal action and the consciousness of law. ${ }^{32}$ Mankowski's illuminating long and diversified list of aspects and perspectives for the sub-declination of our topic indicates that there is no consented systematic approach. ${ }^{33}$ We have to accept that researchers follow their personal preferences when it amounts to such a 'Gesamtschau'. ${ }^{44}$ The French 'Dictionnaire de la culture juridique ${ }^{35}$ does not offer much guidance as to its understanding of legal culture; its modus operandi seems to be a learned eclecticism assuming that some 'vue d'ensemble' (overarching perspective) will emerge in the course of events.

\section{On the Relevance of the 'Culture-Factor' in Comparison}

Though the relationship between law and culture is evident, it is not clear what that means for the comparative enterprise. Of course, everybody would probably subscribe to the appealing title of the reader edited by Legrand 'Comparer les droits, résolument'. ${ }^{36}$ Yet, on second thought, this addendum to his provocative dictum 'que la comparaison sera CULTURELLE ou ne sera pas $^{37}$ does not offer much additional guidance. Does it call for a deeper scrutiny, for more zeal or more dedication to the cause? In his introduction Legrand offers an authentic interpretation in that he pleads against positivism and in favour

31 Friedman, Blankenburg on Legal Culture: Some Comments in Soziologie des Rechts: Festschrift fur Erhard Blankenburg zum 60. Geburtstag, eds. Brandt and Strempel (Nomos 1998) pp. 381 and 383.

32 Blankenburg, Indikatorenvergleich der Rechtskulturen in der Bundesrepublik und den Niederlanden, 6 Zeitschrift für Rechtssoziologie (1985), pp. 255 and 257 et seq.

33 Mankowski 2009. The outline of his book (note 6) will be a source of inspiration for further systematisation. Yet, I agree with Mankowski that we should not overdo it since life is colourful and reality is disparate: Mankowski 2016 p. 504.

$34 \quad$ Bell 2009 p. 278 also favours this term ('vue d'ensemble du système juridique').

35 Alland and Rials (eds.), Dictionnaire de la culture juridique (Presses Universitaires de France 2003). Much more convincing in this respect Nuotio, Melander and Huomo-Kettunen (eds.), Introduction into Finnish Law and Legal Culture (Forum Iuris 2012).

$36 \quad$ See Legrand 2009.

$37 \quad$ See Legrand 2015. 
of ' l'alterite'. ${ }^{38}$ Though this introduction reveals a profound thinker with a poetic touch it remains somewhat vague as to the concrete guidance.

Generally speaking, a culture-oriented comparison calls for an increased sensitivity for context. This methodological requirement is, as such, not contested among comparative lawyers. ${ }^{39}$ Still, Legrand's dictum identifies and separates different camps of comparatists. It is, so to speak, the password to enter the congregation of culture-oriented comparatists. I would like to question the inherent exclusionary touch of Legrand's statement, since, in its rigidity, it may discourage from engaging in comparative law. It should certainly not dissuade us from concrete comparative projects, nor should it be read as an invitation to disregard the positive law. Comparison is above all guided by the maxim 'learning by doing'. Even beginners will soon have learned to double-check their positivistic project by context-oriented considerations. What may have looked like a detour in the beginning may, in the course of the undertaking, turn out to be the direttissima. In that sense, we might want to take Legrand's statement as a reminder that curiosity is perhaps the primary virtue of a good comparatist.

Over time, our young researcher will realise that legal systems have particular trademarks, a unique set of primary normative aspirations which proliferate the whole system and which dictate the knitting pattern of different legal issues. For the U. S. A., freedom of speech, the prohibition of racial discrimination and federalism ${ }^{40}$ form a triad which has been shaped early in American history and which, today, constitutes the recurrent knitting pattern for the settlement of major conflicts. Other legal systems will subscribe to a similar or a different set of basic premises which we should always take into account when called upon to give advice on a specific issue.

Difference will also turn up on the level of principles. Subscribing to the same principle does not mean that the practice looks alike. The understanding and the application of the principle in the daily practice may differ due to countervailing tendencies. Thus, France was upset when Dominique Strauss-Kahn was presented in handcuffs in front of the assembled media which would have constituted a criminal offence in France. ${ }^{41}$ In the U. S. A., the 'perpetrators walk' constitutes an almost uncontested normality though the prosecution authorities in both countries are bound by the same (really?) presumption

38 Legrand, Au lieu de soi, in: Legrand 2009 p. 11; also idem Legrand 2015 p. 49 et seq.

39 For an overview on the methods of comparative law cf. Eser, Strafrechtsvergleichung: Entwicklung - Ziele - Methoden in Strukturvergleich strafrechtlicher Verantwortlichkeit und Sanktionierung in Europa, eds. Eser and Perron (Duncker \& Humblot 2015) p. 929. Eser refers to the 'culture question' in several passages of this magnum opus, without, however, devoting a chapter of its own to it.

$40 \quad$ E.g. Breyer, Active Liberty (Vintage Books 2006) pp. 39 (Speech), 56 (Federalism) and 75 (Affirmative Action).

$41 \quad$ Cf. Le Monde, 21 May 2011, p. 4. 
of innocence. ${ }^{42}$ Evidently, the image of the sheriff's successful fight against the 'crooks' allows for a rougher approach as to what a suspect has to endure. This goes to show that law is not a product of bureaucracy. The structural premises of law dwell on dispositions and habits of the particular society which have emerged through a longer process and will continue to do so following Hans Meyer's dictum that the legislator does not make the law but that he just makes the law bind. ${ }^{43}$

\section{Illustrandi Causa}

Due to the diffusiveness of the term 'culture' it would certainly be of help if we could become a bit more explicit. Geertz has sensitized us for the meaningful detail. I have rather emphasized the idea of the background melody. These positions need not be in contradiction with each other. The 'perpetrators walk' is an example which combines both aspects. Other striking examples may relate to the category of symbols and rituals which tend to incarnate the background melody of a legal system. ${ }^{44}$ Admittedly, my attempt to overcome mere theorizing will still remain in the abstract, 'heavy stuff', since I will draw my examples from basic concepts.

(1) I start this albeit brief rehearsal with the notion of law. Of course, I do not intend to embark on a general discourse on law. I shall restrict myself to a few comments on the relevance of law for a particular society. This relevance is determined by the control potential and by the institutional set-up. We tend to rely on 'a formal definition of the le$\mathrm{gal}^{45}$ and on the existence of an executive machinery, normally attached to the state. This understanding of law or better the belief in the (dominant) role of law is, however, by no means universal.

To begin with, some lawyers needed to be told by sociologists that law is not the only system of social control, but that it co-exists with other systems of norms. Legal

42 For a thorough comparative overview e.g. Stuckenberg, Untersuchungen zur Unschuldsvermutung (de Gruyter 1998).

43 Meyer, Stellung und Aufgaben des Bundesministeriums der Justiz nach dem Auftrag des Grundgesetzes in Vom Reichsjustizamt zum Bundesministerium der Justiz, ed. Bundesministerium der Justiz (Bundesanzeiger Verlag 1977) pp. 443 and 455.

44 As to the legitimizing role of the ceremonial in the English legal system cf. Bourdieu, Sur l'État, Raison d'agir (Seuil 2012) p. 48. Kunz, Die Kulturgebundenheit des Strafrechts und seine Übertragbarkeit in fremde Rechtskreise in Strafrechtsvergleichung als Kulturvergleich, eds. Streng and Kett-Straub (Mohr Siebeck 2012) pp. 145 and 148, has emphasized the culturespecific aspects of the presentation of law.

45 Glenn, Comparative Legal Families and Comparative Legal Traditions in The Oxford Handbook of Comparative Law, eds. Reimann and Zimmermann (Oxford University Press 2008) pp. 421 and 428. 
philosophers like Neil MacCormick have seconded this motion. ${ }^{46}$ In his book The End of Law ${ }^{27} \mathrm{O}^{\prime}$ Hagan has even addressed the question whether law and the state are not just withering away. Though abolitionist tendencies, fueled by communitarian approaches, seem to belong to a distant past, the idea of a normative pluralism is still on the agenda in particular in respect of the international normative interaction imposed by the internationalization of law. Also, distinct differences as to the relationship between law and democracy account for the ranking of law in different societies. For example, France has, in the past, in the footsteps of Rousseau and Jacobinism, favoured an alliance between la volonté générale and an administration entrusted with its execution. In consequence, the Rechtsstaat (Etat de droit) is a latecomer on the French scene. ${ }^{48}$ At present, we can detect tendencies to downplay the importance of law in Poland by curtailing the powers of the Courts; ${ }^{49}$ this seems to be a distant echo of Rousseau. The modern substantive German Rechtsstaats-concept is a product of the deep downfall during the Nazi-period. Yet, Germans have always cherished a special relationship to the law well documented in Kleist's tale 'Michael Kohlhaas. ${ }^{50}$ Noll has, in comparing Germany and Switzerland, coined the provocative formula that in Germany democracy is deficient, whereas in Switzerland this holds true for the Rechtsstaat..$^{51}$ My own extrapolation of a statement by Habermas ${ }^{52}$ that law is the language of democracy may indeed not meet general approval.

As compared to Far Eastern countries, these inner-European differences appear to be niceties. Far Eastern societies seem to take a totally different approach to law or to the idea of a legal system. ${ }^{53}$ Granet's assessment of what constitutes the Chinese everyday morality is as follows: neither God nor the law. ${ }^{54}$ We could also bring it onto the formula: 'Confucianism and the emperor'. Rouland even contends: 'L'histoire du droit en Chine

$46 \quad$ E.g. MacCormick, Institutions of Law (Oxford University Press 2008) pp. 285-289.

$47 \quad$ O'Hagan, The End of Law? (Basil Blackwell 1984).

48 Cf. Kimmel, Von der Jakobinischen Republik zur rechtsstaatlichen Demokratie in Frankreich Jahrbuch 2001, eds. Albertin et al. (Leske \& Budrich 2001) p. 51.

49 E.g. Süddeutsche Zeitung, 14 July 2016, p. 6; Süddeutsche Zeitung, 22 Februry 2017, p. 9; Süddeutsche Zeitung, 18 July 2017, p. 6; Süddeutsche Zeitung, 19 July 2017, p. 6.

50 Cf. Jung, Michael Kohlhaas or the Germans and Their Law, Oñati Legal Series (online), 4 (6), $1124-1132<$ http ://ssrn.com/abstract=2523819> [Last checked on 18 July 2017].

$51 \quad$ Noll, Ist die Schweiz ein Rechtsstaat? in Gedanken über Unruhe und Ordnung, ed. Noll (Pendo 1985) pp. 234 and 237.

52 Habermas, Über den inneren Zusammenhang von Rechtsstaat und Demokratie in Die Einbeziehung des Anderen, ed. Habermas (Suhrkamp 1996) pp. 293 and 301 ('Die demokratische Idee der Selbstgesetzgebung muß sich im Medium des Rechts selbst Geltung verschaffen').

$53 \quad$ As a matter of fact, Glenn 2008 p. 435 contends: 'Western legal traditions are the only ones which have developed the concept of a legal system'.

$54 \quad$ Granet, Das chinesische Denken, 5th ed. (Suhrkamp 1997) p. 318. 
est largement celle de son absence. ${ }^{55}$ Though this may be an exaggeration it is a fact that there has been little theorizing about law in China. Law was primarily conceived of as an instrument of power. ${ }^{56}$ This explains the pre-dominance of criminal law. Furthermore, Hilgendorf alludes to the missing separation of Law and morality and to the dominance of the concept of duty in Confucianism. ${ }^{57}$ The family and the group are the central poles of reference and allegiance. This holds true for Japan as well. ${ }^{58}$ Here rules and law do not play such a decisive role in the maintenance of public order. At least, in actual practice, the mechanisms of informal social control, fueled by social hierarchy and the desire to maintain social harmony, still carry a substantial part of the 'control load'. We need to be careful not to overstate this point. Ida for example insists on the emancipatory role of law and rebukes a 'cultural determinism. He believes that the reference to culture could serve as a strategy of immunization against progress. ${ }^{59}$ This is, of course, a voice from inside Japan, yet, a voice of a legal scholar who may vest more hope into the law than the public at large. Still, our stereotype statements on the Far Eastern disregard for the law may be open to reinterpretation. ${ }^{60}$

The juxtaposition 'group vs. individual' permeates the African debate as well. Consequently, the African Charter on Human and Peoples' Rights does not only provide rights, but duties as well. Law is rather considered to be a European export article, a product of colonisation. Mbaye has captured this distance towards law in the formula: 'Généralement en Afrique, selon les mours et coutumes traditionnelles, se tenir loin du prétoire, n'avoir jamais à plaider tant comme demandeur que comme défendeur est un signe de sagesse et une raison d'être fier de sa moralité et de son comportement social. ${ }^{61}$ The administration

55 Rouland, Introduction historique du droit (Presses Universitaires de France 1998) p. 41. ('The history of law in China is largely that of its absence').

56 MacCormack, Law and Punishment: the Western and the Traditional Chinese Legal Mind in The Legal Mind. Essays for Tony Honoré, eds. MacCormick and Birks (Oxford University Press 1986) pp. 235 and 251.

57 Hilgendorf, Das chinesische Strafrechtssystem im sozio-kulturellen Kontext in Ostasiatisches Strafrecht, ed. Hilgendorf (Mohr Siebeck 2010) p. 114 et seq. Illuminating on the relevance of Confucian thought also Chapter 9 'A Confucian Legal Tradition: Make it New (with Marx?)' in Glenn, Legal Traditions of the World, $4^{\text {th }}$ ed. (Oxford University Press 2010) p. 319.

58 Rohlen, Japanische Ordnungsprinzipien: Bindung, Autorität und Routine in Anleitung zur Neugier. Grundlagen japanischer Erziehung, ed. Elschenbroich (Suhrkamp 1996) pp. 92 and 102.

$59 \quad$ Ida, Strafrechtsvergleich als Kulturvergleich? in Streng and Kett-Straub 2012 pp. 23 and 26.

60 See, concerning Japan, Rosen 2008 p. 95 et seq.

61 Mbaye, Les Droits de l'Homme en Afrique, $2^{\text {nd }}$ ed. (Pedone 2002) p. 72. ('Generally speaking, it is, according to the traditional African custom, a sign of wisdom and a reason to be proud of one's morality and social behaviour to keep far off the court-room and to never have to plead a case either as plaintiff or as a defendant'). 
of justice will in many African countries be confronted with the challenge to reconcile tradition and modernity. ${ }^{62}$

Of course, this distant approach to law is, outside the world of lawyers, a common phenomenon. In that sense, the divide between those who administer the law and those who are being administered ${ }^{63}$ imposes itself on our topic. Also, we have to concede that there are universal matter-of-fact developments which will leave their mark all over the world. However, if Nottage downplays the cultural component in his discourse on Japan, dwelling on the example of product liability, ${ }^{64}$ he cannot really dismantle the power of traditional concepts of conflict resolution. He only demonstrates that their relevance differs from problem to problem and from 'Lebenswelt' to 'Lebenswelt'. Or, in more general terms, the cultural impact is of lesser importance with regulatory norms as compared to morally sensitive areas. ${ }^{65}$

(2) The next candidate is the notion of punishment. Of course, punishment is a wellknown category in any legal system. This does, however, not mean that punishment is an uncontested concept. There are divergent positions as to the essence of punishment, as to the forms of punishment and as to the use of punishment. The German dichotomies 'punishment versus measure' on the one hand and 'punishment versus administrative fine' on the other stand for a certain sophistication of the system of penal sanctions which is not altogether common. Not surprisingly, Delmas-Marty has used the term 'matière pénale' of Art. 6 ECHR to illustrate the fuzziness of law ('le flou du droit') and the role of fuzzy logics in legal thought. ${ }^{66}$ All this would, however, rather pass as a 'technicality', as a treat for lawyers.

Garland has, from a criminological point of view, reached beyond that and adopted 'culture' as the central theme not only in his trilogy Punishment and Modern Society, ${ }^{67}$

62 Kamto, Une justice entre tradition et modernité, Nr. 156 (spécial) Afrique contemporaine (1990) p. 57.

63 This formula has been coined by Bankowski and Mungham, Laypeople and Lawpeople and the Administration of the Lower Courts, 9 International Journal of the Sociology of Law (1981) pp. 85 and 99.

64 Nottage, The Still-Birth and Re-birth of Product Liability in Japan in Adapting Legal Cultures, eds. Nelken and Feest (Hart 2001) p. 147.

65 Cf. Kunz 2012.

66 For the first time in Delmas-Marty, Le flou du droit (Presses Universitaires de France 1986) p. 317.

67 Garland, Punishment and Modern Society (Oxford University Press 1991). 
The Culture of Control ${ }^{68}$ and Peculiar Institution, ${ }^{69}$ but also in many of his articles. ${ }^{70} \mathrm{He}$ starts out by theorizing about penal sensibilities, the expressive use of punishment, and a rising punitiveness to end up with the role of the death penalty in the U. S. A. This 'peculiar institution' seems to be the example for the cultural background of punitiveness. ${ }^{71}$ Whereas, in the European Union, the prohibition of the death penalty belongs to the acquis communautaire, it is still being practiced in many countries. In countries like China and the U. S. A., the traditional or pseudo-religious background for the retention of the death penalty is obvious. Likewise, the practice of corporal punishment in some Islamic states is being propagated as a symbol of adhesion to the true faith. ${ }^{72}$ For others, it raises questions as to the level of civilization of such a religious creed. Finally, the severity of sentences, the rate of prisoners ${ }^{73}$ and the prison regime ${ }^{74}$ may also pass as a test for the degree of civilization of that particular society.

Despite the cultural embeddedness of punishment, comparing systems of sanctions has a long history. As a matter of fact, the system of sanctions has acted as a catalyzer for the development of schemes for the protection of human rights with their inherent harmonization effect. ${ }^{75}$ Also, major currents in criminal policy will rarely be limited to a single country. Rather, criminal policy has always been an object of a busy import/export 'trade. This holds true in particular for the list of non-custodial sanctions which have emerged over times, starting with probation and ending with community service, compensation and electronic monitoring. The manifold international fora offer a platform for exchange in criminal policy matters, thus promoting a diffusion of ideas and models.

Of course, we are far from uniformity. Yet, those who want to depart from the mainstream feel obliged to justify their decision. At present, a great deal of this interaction takes place in the field of sanctioning. Here, the popular punitiveness in the U. S. A. has

68 Garland, The Culture of Control (Oxford University Press 2001).

69 Garland, Peculiar Institution (Oxford University Press 2010).

70 Garland, A culturalist theory of punishment?, 11 Punishment \& Society (2009) p. 259; Garland, Concepts of Culture in the Sociology of Punishment in Travels of the Criminal Question, eds. Melossi, Sozzo and Sparks (Hart 2011) p. 17.

71 Garland 2010 attributes this retentionist approach to the death penalty in the U.S.A. mainly to 'local democracy'. In my opinion this aspect is only of a secondary nature.

72 Illuminating as to a certain approximation of Islamic and secular principles in criminal law, Bohlander and Hedayati-Kakhki, Criminal Justice under Shari' ah in the $21^{\text {st }}$ century - An InterCultural View, 23 Arab Law Quarterly (2009) p. 417.

73 It is a matter of controversy whether the rate of prisoners can be a yard-stick for the punitiveness of a society cf. Jung, Sanktionensysteme und Menschenrechte (Haupt 1992) p. 48 vs. Pease, CrossNational Imprisonment Rates, 34 British Journal of Criminology (1994) p. 116.

74 E.g. Winston Churchill's famous dictum in the House of Commons on July 20, 1910: 'The moral temper of the public in regard to the treatment of crime and criminals is one of the most unfailing tests of the civilisation of any country'. (Hansard XIX Col. 1354).

$75 \quad$ For a general account e.g. Jung 1992. 
mobilized resistance in Europe. ${ }^{76}$ Apparently, Greve believes in (more) cultural diversification as a barrier against the oppressive crime control wave. ${ }^{77} \mathrm{I}$ rather trust in the standard-setting function of international institutions like the European Court of Human Rights, the European Committee for the Prevention of Torture (CPT), the Council of Europe's Recommendations and the many Conventions sponsored by this institution. I am, in this respect, putting the emphasis on the activities of the Council of Europe, because its instruments are, by and large, more cogent than the comparable instruments of the United Nations. Guided by an evaluative comparative law and overarching principles, they have, time and again, been able to curtail culture-oriented offsprings of domestic systems of sanctions. However, due to the majestic vagueness of human rights and the margin of appreciation of the member states ${ }^{78}$ the potential for harmonization is limited.

(3) Procedures enjoy a particular longevity. Do they therefore qualify as a telling example for the relationship between law and culture? We like to refer to the 'sporting theory of justice' used to qualify the Anglo-American type of criminal procedure ${ }^{79}$ as the unfailing proof of the connection between law and culture. 'Fairness', its offspring, has conquered the world, not only that of procedure. ${ }^{80}$ It might well be, however, that this terminology does not point to a genetic link, but that we are just explaining a particular structure by using pictures that everybody is familiar with. Still, the reference to sports, and thus to competition, is not without significance since it hints at the relationship between state structure and procedure. Procedures reveal different approaches to conflicts and their settlement and to the institutions entrusted with this business. ${ }^{81}$

Parading the different institutions may best show the amalgam between 'law and culture' in conflict resolution. We keep being fascinated by the institution of the jury, this small democratic panel which stands pars pro toto for the Anglo-American trial though, in practice, it plays, quantitatively speaking, a minor role. Due to the long tradition which goes back to the Magna Charta ${ }^{82}$ the jury trial is more than just a legal institution. It has

76 See my own contribution Wider die neue Straflust!, 153 Goltdammer's Archiv für Strafrecht (2006) p. 724

77 Greve 2010 p. 491 et seq.

78 On the margin of appreciation cf. Jung, Upgrade für die margin of appreciation? in Herausforderungen an Staat und Verfassung. Völkerrecht - Europarecht - Menschenrechte. Liber Amicorum für Torsten Stein, ed. Calliess (Nomos 2015) p. 976.

79 Herrmann, Die Reform der Hauptverhandlung nach dem Vorbild des anglo-amerikanischen Verfahrens (Röhrscheid 1971) p. 153.

80 Cf. Jung, Der Grundsatz des fair trial in rechtsvergleichender Sicht in Verfahrensrecht am Ausgang des 20. Jahrhunderts. Festschrift für Gerhard Lüke, eds. Prütting and Rüßmann (Beck 1997) p. 323.

81 Still unsurpassed Damaška, The Faces of Justice and State Authority (Yale University Press 1986). Cf. also Hörnle, Unterschiede zwischen Strafverfahrensordnungen und ihre kulturellen Hintergünde, 117 Zeitschrift für die gesamte Strafrechtswssenschaft (2005) p. 801.

82 E.g. Lord Devlin, Trial by Jury, Revised Edition (Stevens 1966) p. 3 et seq. 
become part of everyday life, of the cultural setting. This has, in recent times, been boosted by the many trial films, starting with 'Twelve Angry Men', which have popularized the jury trial as the prototype of courtroom justice. This close attachment to the jury may explain why this institution ranks on top of the U. S. American list of 'export-desiderata' in judicial matters and why U. S. American lawyers have a tendency to confound lay justice with the jury question, thus marginalizing the many models of mixed tribunals which exist throughout the world. ${ }^{83}$

As a matter of fact, our understanding of procedures seems to be determined by their 'showpieces'. Whereas the jury symbolizes the Anglo-American procedure, the instructing judge is the 'showpiece' of the French criminal procedure. ${ }^{84}$ Instructing judges are surrounded by a similar myth, also cultivated by fiction and film. In particular in politically sensitive cases, the instructing judge represents the lonely rider against the political establishment. In a way, jury and instructing judge resemble each other: they are both, quantitatively speaking on the retreat. Yet, they are still both indicative of the basic feature of the particular procedure inasmuch as they mark its factually decisive phase, here the court-room, there the bureaux during the preliminary phase of the process.

In actual fact, the prosecutor has been a much more successful French export article, even with regard to the terminology, since it combines executive influence with the idea of the division of power in criminal justice, an emanation of the strong state with, however, in-built restraints. Of course, prosecutors are not alike. Much depends on the structure of the state: France, for instance, is a central state, whereas Germany is a federal state. In many countries, prosecutors are guided by the principle of discretion, in others by the principle of compulsory prosecution or a mix of compulsory prosecution and discretion. Their link with the executive, hence their independence, varies, the Italian prosecutor being, due to his inamovabilità, the most independent of them. Therefore prosecutors are not identical figures, but rather brothers or sisters. ${ }^{85}$

Generally speaking, the structure of the judiciary, the role of judges and the extent of lay participation in adjudication may vary considerably from jurisdiction to jurisdiction. This is very much related to the cultural bias in favour or against professionalism in adjudication. ${ }^{86}$

83 E.g. Jung, In Defence of Lay Participation in Festschrift für Hans-Heiner Kühne zum 70. Geburtstag, eds. Esser et al. (Müller 2013) p. 251.

84 For the history of the instructing judge cf. Clère and Farcy (eds.), Le juge d'instruction. Approches historiques (Editions Universitaires de Dijon 2010).

85 E.g. Jung, Le ministère public: portrait d'une institution, 15 Archives de politique criminelle (1993), p. 15; Lazerges (ed.), Figures du parquet (Presses Universitaires de France 2006).

86 Cf. Mankowski 2009 p. 326; idem, 2016 p. 306; Jung, Richterbilder. Ein interkultureller Vergleich, (Nomos 2006). 
Moreover, the institution of the jury has already alluded to the fact that conflict resolution cannot be conceived of as legal exercise (only). By way of 'jury nullification' juries have always brought to bear considerations which have reached beyond the law. ${ }^{87}$ In particular smaller societies have cherished the idea that (real) conflict resolution is about mending broken social relations by bringing the parties on speaking terms again. ${ }^{88}$ This requires a compromise culture and the respect for the individuality of each case. Such models are not at ease, to say the least, in a 'society of strangers' (Nader) even though the mediation movement shows that it is not a lost cause.

\section{Concluding Remarks}

I have, on purpose, avoided the term 'conclusion'. Our topic does not allow a clear-cut conclusion. At best, we might end up with a somewhat better, but still vague notion of what 'law and culture' is about. Also, this notion is tainted by subjectivism. This is my view, the view of a German criminal lawyer!

To begin with, a German lawyer will approach the topic with a particular background. In that sense, comparative law perspectives tend to be somewhat personal. Since comparing resembles traveling it is very much a personal experience. ${ }^{89}$ In addition to that the culture-discourse is tainted by national predispositions and stereotypes: The German 'Kampf ums Recht'90 might strike the French lawyer as totally inelegant.

Moreover, criminal law is a branch of law which is very much imbued with culture. Private lawyers may arrive at slightly different conclusions.

Still almost everybody will agree that culture introduces an element of relativity. The relativity will vary, depending on the nature of the problem. Therefore the simple answer to our question is: we have to compare laws, but we should not disentangle them from their cultural background. This calls for a more open culture-sensitive approach to comparison. Yet, normally, a true interest in foreign laws should go hand in hand with an interest in other cultures.

87 See Jung, Die Jury und ihr Entscheidungsgegenstand - zur „Jury Nullification“ in Prozessuales Denken als Innovationsanreiz für das materielle Strafrecht, eds. Pieth and Seelmann (Helbing \& Lichtenhain 2006) p. 43.

88 E. g. Rosen, The Anthropology of Justice (Cambridge University Press 1989) pp. 17 and 37 with reference to the kadi-system.

89 Cf. the very personal account by Tunc, Les joies et les peines d'un comparatiste in Entwicklungslinien in Recht und Wirtschaft, eds. Jung, Kroeber-Riel and Wadle (Schäffer 1990) p. 123.

90 Cf. von Ihering, Der Kampf ums Recht (Trapeza 2012) (Reprint of the original of 1894). 
Rather than using the term culture, Glenn, in his magnum opus, speaks of legal tradition. Certainly culture has a strong affinity to tradition. Yet, I prefer to speak of legal 'culture' because of the 'fluidity' of this term. Also 'tradition' tends to over-emphasize law and its administrators. The term culture invites to a stocktaking of a more general nature. This should embrace the social, religious and ideological characteristics of a society in order to understand that legal orders are the normative aspirations of a particular society with its particular life style and priorities. Not surprisingly, these characteristics are brought to bear in rituals and symbols offering 'social abbreviations' which help promoting social stability and cohesiveness. In that sense, even more cross-cultural research on (legal) rituals is needed.

The human rights discourse provides some common ground, even alluding to the emergence of a common, though still fragile, legal culture.$^{91}$ Of course, the universality of Human Rights is still a contested issue due to rivaling Human Rights systems. ${ }^{92}$ Reconciling cultural diversity with the idea of universal Human Rights is indeed a permanent challenge. ${ }^{93}$ Yet, this discourse offers at least a vision. It hints at a deeply rooted notion if not of justice but of limits. ${ }^{94}$

Law, and this goes for sure, is not a mere technique. It is also a cultural phenomenon. Of course, comparative lawyers need not be experts in 'cultural studies'. Yet, they should be prepared to reach out beyond the law books and court-reports and to invest more in field work and interdisciplinary discourse in order to arrive at a more profound knowledge of 'the other'..$^{95}$

91 Tuori, Critical Legal Positivism (Ashgate 2002) p. 196 assumes a pre-existing common ground as part of his concept of a 'multilayered legal order': 'When we, in our archeological journey into the law penetrate deeper we can detect common features crossing cultural differences, such as fundamental human rights principles'.

92 Cf. Trechsel, Inflation im Bereich der Menschenrechte?, 1 Zeitschrift für Europarechtliche Studien (1998) p. 371.

93 On this issue e.g. Kassedjian, Le droit international collaboratif (Pedone 2016), p. 74 et seq.

94 Toying with Camus' statement: 'Es gibt keine Gerechtigkeit, es gibt nur Grenzen'. (Tagebücher 1935-1951), (Rowohlt 1997) p. 389.

95 Into the same direction the remarkable plea for a culture-oriented comparative criminal law by Beck, Strafrecht im interkulturellen Dialog in Strafrechtsvergleichung als Problem und Lösung, eds. Beck, Burchard and Fateh-Moghadam (Nomos 2011) p. 65 et seq. 